\title{
Penentuan Kadar Garam Kultur Hara untuk Seleksi Toleransi Salinitas pada Padi Lokal Bengkulu
}

\author{
Determination of Salt Consentration In Hydroponics \\ for Land Rase Rice Salinity Tolerant Media \\ Rustikawati*, Marulak Simarmata, Edhi Turmudi dan Catur Herison \\ Jurusan Budidaya Pertanian, Fakultas Pertanian, Universitas Bengkulu \\ *: tika_ngrh@yahoo.com
}

\begin{abstract}
Bengkulu province area elevating from $0 \mathrm{~m}$ to over $1000 \mathrm{~m}$ above sea level possesses high rice germplasm diversity. To obtain salinity controlling gene(s) from those germplasm, it is required to determine a suitable protocol. This research was objected to determine $\mathrm{NaCl}$ concentration to select Bengkulu rice landraces. The standard most salinity tolerant genotype used in this research was 'Kuning', a local variety usually grown on tidal area of Seluma Regency for generations. The growing media was Yoshida nutrient culture supplemented with a series of $\mathrm{NaCl}$ concentration of 0, 2000,4000,6000, 8000 or 10000 ppm. Observation was done every 2 days to find out the response pattern of rice seedling growth on different $\mathrm{NaCl}$ concentration. $\mathrm{NaCl}$ stress level was determined at 90\% seedling dead (LC90) at the eighth day. The results showed that the increase of plant height was deceased at concentration of $6000 \mathrm{ppm}$. Based on the mathematical equation generated from the percent mortality data distribution, the $L C_{90}$ was at $3910 \mathrm{ppm} \mathrm{NaCl}$ concentration.
\end{abstract}

Key words: rice, salt tolerance, protocol, Bengkulu

\begin{abstract}
ABSTRAK
Provinsi Bengkulu dengan topografi mulai dari 0 mdpl hingga di atas $1000 \mathrm{mdpl}$, memiliki keragaman plasma nutfah padi yang tinggi. Untuk mendapatkan sumber gen toleran salin pada plasma nutfah tersebut perlu ditetapkan protokol yang tepat untuk seleksi terhadap salinitas. Penelitian ini bertujuan untuk menentukan konsentrasi $\mathrm{NaCl}$ yang dapat digunakan untuk seleksi padi lokal Bengkulu. Genotipe yang digunakan sebagai indikator adalah padi Kuning yang telah dibudidayakan petani pada sawah pasang surut pantai Kabupaten Seluma. Media yang digunakan adalah kultur hara Yoshida dengan penambahan $\mathrm{NaCl}$ berseri pada konsentrasi 2000, 4000, 6000, 8000 dan $10000 \mathrm{ppm}$. Untuk mengetahui pola respon pada setiap konsentrasi diamati tinggi tanaman setiap 2 hari. Tingkat stress $\mathrm{NaCl}$ ditetapkan sebesar $90 \%\left(\mathrm{LC}_{90}\right)$ pada hari ke 8 . Hasil penelitian menunjukkan bahwa penambahan tinggi tanaman tidak nyata pada media dengan penambahan $\mathrm{NaCl} 6000 \mathrm{mg} / \mathrm{l}$. Berdasarkan persamaan matematik dari sebaran data persen tanaman hidup diperoleh nilai $\mathrm{LC}_{90}$ pada konsentrasi $\mathrm{NaCl} 3910$ ppm.
\end{abstract}

Kata kunci: padi lokal, toleran salin, kultur hara 


\section{PENDAHULUAN}

Di Indonesia lahan marginal dijumpai baik berupa lahan gambut, lahan sulfat masam, rawa pasang surut, tanah Ultisol (Suprapto, 2002), salin, dan sodik/alkalin (Bhumbla dan Abrol 1978). Lahan salin lebih banyak terdapat disekitar pesisir pantai karena terjadinya iklim global dan naiknya permukaan air laut (Ismail, 2007). Propinsi Bengkulu memiliki luas wilayah 1.978.870 ha dengan wilayah pesisir dan daerah dengan ketinggian kurang dari $100 \mathrm{~m}$ di atas permukaan laut mencapai mencapai 708.435 ha $(35.80 \%)$ (Anonim, 2012a). Menurut Muttaqiena (2009) wilayah pesisir di Indonesia memiliki karakteristik fisik yang berbeda-beda dan pengelolaannya harus disesuaikan dengan potensi lokal masing-masing wila-yah. Oleh karena itu pengelolaan padi lokal dari Bengkulu harus disesuaikan dengan wilayah di Bengkulu. Pada tahun 2010 Simarmata et al. (2010) berhasil mengkoleksi 40 genotipe padi lokal dan dua tahun kemudian Pujiwati et al (2012) mengkoleksi 75 genotipe padi lokal yang berbeda. Beberapa genotype diantaranya adalah genotype yang telah adaptif lahan pesisir namun produksinya masih sangat rendah. Salah satu upaya untuk meningkatkan produktivitas lahan pesisir adalah dengan menanam kultivar unggul yang adaptif cekaman salin.

Keberhasilan program pemulia-an untuk toleransi terhadap salinitas sangat ditentukan oleh metode seleksi yang efektif. Untuk mempersingkat waktu seleksi perlu dikembangkan metode seleksi dapat dilakukan pada fase bibit. Metode tersebut sangat bermanfaat bagi pemulia tanaman yang mengembangkan kultivar toleran salin. Berbagai teknik seleksi dini untuk toleransi tanaman padi terhadap salinitas telah dilakukan, namun variasi sensitivitas tanaman padi sangat dipengaruhi oleh fase pertumbuhan. Lafitte et al. (2004), menyatakan bahwa tanaman padi cukup toleran terhadap cekaman salinitas pada fase perkecambahan, pertumbuhan vegetatif aktif dan fase generatif. Sebaliknya sangat sensitif selama fase pertumbuhan kecambah. Anonim (2012b) mempublikasikan protokol seleksi bibit padi berumur 1 sampai 2 minggu dengan hidroponik pada konsentrasi $\mathrm{NaCl} 10 \mathrm{dS} / \mathrm{m}$ (6.4 g/l). Blake dan Munns (2011) melakukan seleksi pada fase kecambah berumur 2 sampai 3 hari. Ibnu-Rusd, (2011) mendapatkan bahwa pengujian toleransi terhadap salinitas pada benih padi dengan metode kertas stensil yang terbaik pada konsentrasi 8000 ppm $\mathrm{NaCl}$, namun tidak berkorelasi positif dengan hasil pengujian untuk genotype yang sama di rumah kaca berdasarkan indikator persentase daun mati.

Berdasarkan beberapa hasil diatas maka diperlukan protokol yang aplikatif untuk melakukan seleksi pada padi lokal Bengkulu terhadap salinitas. Salah satu indikator yang dapat digunakan adalah yang adaptif pada wilayah pesisir Bengkulu. Penelitian ini bertujuan untuk menentukan konsentrasi $\mathrm{NaCl}$ yang dapat digunakan untuk seleksi padi lokal Bengkulu.

\section{METODE PENELITIAN}

Penelitian dilakukan di Rumah Kaca Jurusan Budidaya Pertanian Universitas Bengkulu pada Bulan Juni sampai Juli 2014. Genotipe yang digunakan sebagai indikator adalah padi Kuning yaitu padi lokal yang telah dibudidayakan petani pada sawah pasang surut pantai Kabupaten Seluma. Bibit padi diperlakukan pada umur 4 hari setelah semai. Media hidroponik mengandung unsur hara sesuai dengan formula Yoshida et al. (1976) yang terdiri atas 6 larutan stok (5 stok untuk unsur hara makro dan 1 stok unsur hara mikro). Kemasaman larutan 
selama penelitian dipertahankan pada 5.0 dengan menambahkan $\mathrm{NaOH} 1 \mathrm{~N}$ atau $\mathrm{HCl}$ $1 \mathrm{~N}$ sesuai dengan hasil pengukuran setiap 2 hari. Seri konsentrasi $\mathrm{NaCl}$ yang diuji adalah 2000, 4000, 6000, 8000 dan 10000 ppm. Setiap konsentrasi $\mathrm{NaCl}$ diulang 3 kali. Setiap unit percobaan terdiri atas 10 bibit padi yang ditegakkan pada strerofoam dan diapungkan di atas media kultur. Pada media dipasang aerator agar terjadi sirkulasi udara. Pengamatan dilakukan terhadap tinggi tanaman dan persen tanaman hidup pada umur 2, 4, 6, dan 8 hst. Pada akhir pengamatan ditimbang bobot kering seluruh tanaman. Data tinggi dan berat kering tanaman diuji dengan uji $t$, sedangkan data persen tanaman hidup pada hari ke 8 dibuat grafik untuk menentukan konsentrasi $\mathrm{NaCl}$ pada tingkat kematian $90 \%$.

\section{HASIL DAN PEMBAHASAN}

Tinggi tanaman digunakan sebagai variabel pendukung untuk menduga toleransi tanaman padi terhadap salinitas. Pengamatan tinggi tanaman dilakukan secara periodik setiap 2 hari dengan tujuan untuk melihat respon berkurangnya laju pertumbuhan dengan kenaikan konsentrasi $\mathrm{NaCl}$. Hasil pengamatan menunjukkan bahwa tinggi tanaman pada kontrol (tanpa $\mathrm{NaCl}$ ) meningkat pesat dari 2 hingga 8 hari setelah perlakuan. Perbedaan tinggi tanaman sangat nyata berdasarkan uji t (Tabel 1). Perlakuan cekaman $\mathrm{NaCl}$ secara nyata menurunkan laju penambahan tinggi tanaman. Pada cekaman $\mathrm{NaCl} 2000$ ppm, rata-rata tinggi tanaman pada umur 8 hari adalah $10.17 \pm 0.56 \mathrm{~cm}$. Sedangkan pada tanaman kontrol mencapai $15.36 \pm 0.26 \mathrm{~cm}$. Pada perlakuan tersebut berkurangnya tinggi tanaman mencapai 34\%. Namun jika dilihat secara visual, tanaman masih mampu tumbuh dengan baik dengan sedikit gejala keracunan pada ujung daun. Pengurangan tinggi tanaman dibandingkan kontrol secara nyata terjadi pada perlakuan stress $\mathrm{NaCl}$ mulai dari 4000 ppm hingga 10000 ppm. Namun persen pengurangan tinggi dibandingkan kontrol semakin kecil dengan kenaikan konsentrasi $\mathrm{NaCl}$. Gejala tersebut mulai terlihat mulai pengamatan pada 4 hari setelah perlakuan. Bahkan pada perlakuan 8000 ppm dan 10000 ppm tinggi tanaman sudah tidak berbeda nyata. Pada konsentrasi tersebut telah terjadi kematian tanaman akibat keracunan $\mathrm{NaCl}$. Hal ini dapat disimpulkan bahwa konsentrasi 4000 ppm $\mathrm{NaCl}$ adalah titik awal terjadinya gangguan fisiologis tanaman secara nyata. Hal ini sesuai dengan pendapat Hutajulu et al. (2013) yang menyatakan bahwa pengaruh garam yang berlebih terhadap tanaman padi adalah berkurangnya kecepatan perkecambahan, berkurangnya tinggi tanaman.

Tabel 1. Rata-rata tinggi tanaman padi $(\mathrm{cm})$ pada umur 2 sampai 8 hari setelah perlakuan pada kultur hara

\begin{tabular}{ccccc}
\hline $\begin{array}{c}\text { Konsentrasi NaCl } \\
\text { (ppm) }\end{array}$ & $\mathbf{2}$ & $\mathbf{4}$ & $\mathbf{6}$ & $\mathbf{8}$ \\
\cline { 2 - 5 } & $9.45 \pm 0.39$ & $10.44 \pm 0.34$ & $13.36 \pm 0.24$ & $15.36 \pm 0.26$ \\
2000 & $7.93 \pm 0.27$ & $9.18 \pm 0.10$ & $9.35 \pm 0.25$ & $10.17 \pm 0.56$ \\
4000 & $5.92 \pm 0.14$ & $6.38 \pm 0.57$ & $6.85 \pm 0.61$ & $7.34 \pm 1.21$ \\
6000 & $6.07 \pm 0.08$ & $6.15 \pm 0.32$ & $6.24 \pm 0.19$ & $6.24 \pm 0.19$ \\
8000 & $5.56 \pm 1.68$ & $5.81 \pm 2.05$ & $5.57 \pm 0.07$ & $5.57 \pm 0.07$ \\
10000 & $5.44 \pm 0.10$ & $5.52 \pm 0.09$ & $5.53 \pm 0.24$ & $5.53 \pm 0.24$ \\
\hline
\end{tabular}




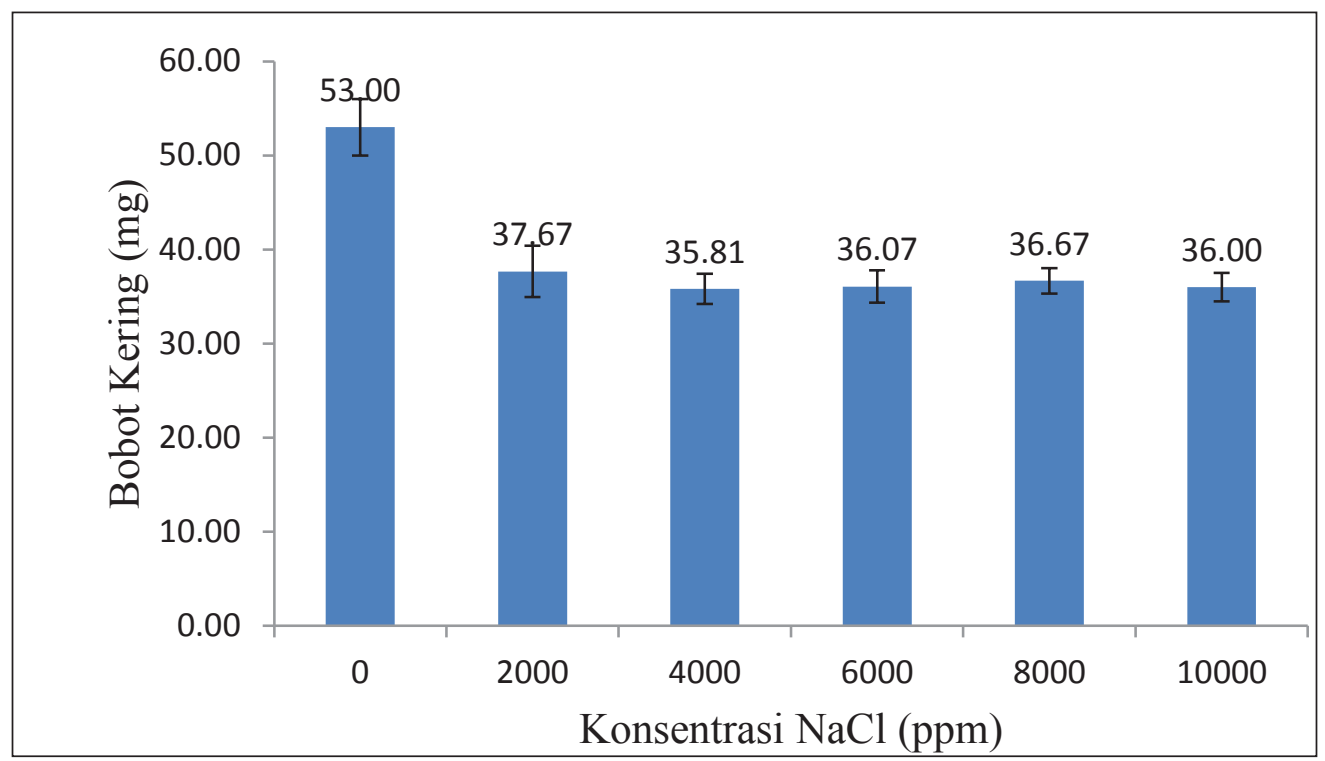

Gambar 1. Grafik bobot kering tanaman pada umur 8 hari setelah perlakuan pada kultur hara

Tabel 2. Rata-rata persen tanaman hidup pada umur 2 sampai 8 hari setelah perlakuan pada kultur hara

\begin{tabular}{ccccc}
\hline $\begin{array}{c}\text { Konsentrasi NaCl } \\
(\mathbf{p p m})\end{array}$ & $\mathbf{2}$ & $\mathbf{4}$ & $\mathbf{6}$ & \multicolumn{1}{c}{$\mathbf{8}$} \\
\cline { 2 - 5 } & 100.00 & 100.00 & 100.00 & 100.00 \\
2000 & 100.00 & 96.67 & 96.67 & 36.67 \\
4000 & 100.00 & 83.33 & 56.67 & 23.33 \\
6000 & 100.00 & 100.00 & 76.67 & 0.00 \\
8000 & 100.00 & 80.00 & 23.33 & 0.00 \\
10000 & 100.00 & 60.00 & 16.67 & 0.00 \\
\hline
\end{tabular}

Selain tinggi tanaman, variabel pendukung yang lain adalah bobot kering tanaman. Pada hari ke 8 seluruh tanaman baik yang masih hidup maupun yang sudah mati karena keracunan $\mathrm{NaCl}$ dioven pada suhu $70^{\circ} \mathrm{C}$ selama 3 hari. Berbeda dengan data tinggi tanaman, bobot kering tanaman turun drastis pada perlakuan $\mathrm{NaCl}$ dibandingkan kontrol. Bahkan mulai cekaman $\mathrm{NaCl} 2000$ ppm hingga 10000 ppm bobot kering tanaman tidak berbeda nyata menurut uji t (Gambar 1). Sementara itu tinggi tanaman pada perlakuan $\mathrm{NaCl} 2000$ ppm masih nyata lebih tinggi dibandingkan perlakuan 4000 ppm. Hal ini menunjukkan bahwa pertambahan tinggi tanaman pada perlakuan $\mathrm{NaCl} 2000$ ppm tidak diikuti dengan penambahan fotosintat. Proses fotosintesis terganggu walau $\mathrm{NaCl}$ diberikan pada konsentrasi rendah. Menurut Suwarno (1985), $\mathrm{NaCl}$ dapat mengganggu proses fisiologis tanaman terhadap dalam tiga aspek yaitu mempengaruhi tekanan osmosis, keseimbangan hara dan sebagai racun. Pada tanaman yang toleran akumulasi $\mathrm{Na}$ dan $\mathrm{Cl}$ dapat dicegah dengan cara mengeksudasikan pada lingkungan sekitar (Levitt, 1980). 


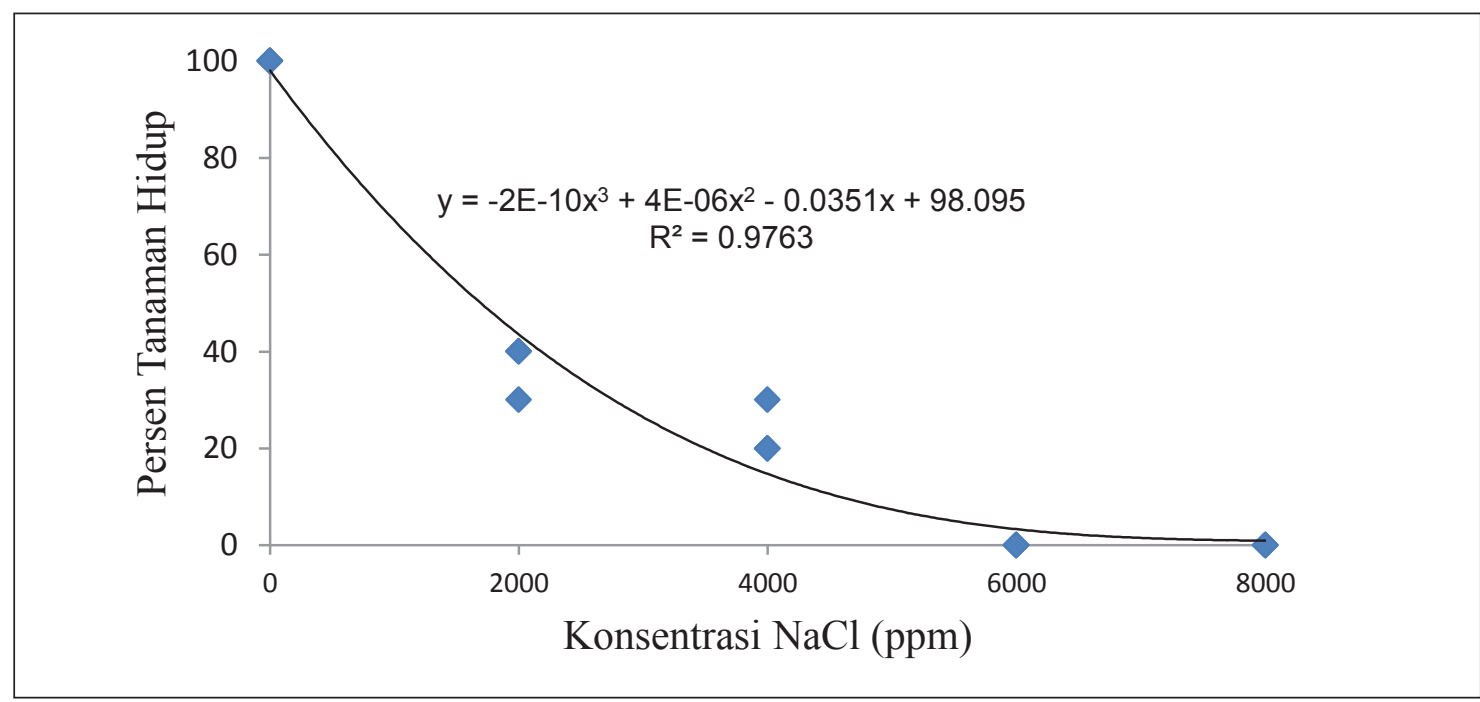

Gambar 2. Grafik persen tanaman hidup pada umur 8 hari setelah perlakuan pada kultur hara

Variabel utama untuk menentukan tingkat seleksi adalah konsentrasi $\mathrm{NaCl}$ pada tingkat kematian 90\%. Kematian tanaman ditandai dengan warna kecoklatan pada seluruh daun. Warna kecoklatan diawali dari bagian pucuk daun secara perlahan hingga ke bagian pangkal. Sebelum muncul warna kecoklatan, gejala awal adalah mengeringnya bagian tepi daun sehingga terlihat daun menggulung. Semakin tinggi konsentrasi $\mathrm{NaCl}$, semakin cepat terjadi kematian tanaman. Pada pengamatan 2 hari setalah perlakuan belum ada tanaman yang mati. Dua hari kemudian mulai terlihat beberapa tanaman mati atau ujung daun mulai kecoklatan. Tanaman yang diperlakukan dengan $\mathrm{NaCl} 10000$ ppm paling banyak mati, namun pada 6000 ppm masih mampu hidup $100 \%$. Terdapat variasi data persen tanaman hidup pada pengamatan tersebut (Tabel 2). Hari keenam setelah perlakuan terdapat tanaman mati pada semua tingkat konsentrasi $\mathrm{NaCl}$. Pada pengamatan tersebut semua daun padi dengan perlakuan diatas 6000 ppm sudah mulai mencoklat dan pada hari ke delapan semua mati. IbnuRusd (2011) menyatakan bahwa tanaman yang mengalami stresgaram umumnya tidak menunjukkan respon kerusakan secara langsung tetapi pertumbuhan yang tertekan dan perubahan secara perlahan. Selanjutnya Levitt (1980) menyatakan bahwa rusaknya daun diakibatkan oleh keracunan $\mathrm{Na}$ yang ditandai dengan mengeringnya bagian tepi daun, demikian juga gejala keracunan $\mathrm{Cl}$. Gejala tersebut sulit dibedakan dengan gejala kekeringan.

Data persen tanaman hidup pada hari ke delapan kemudian dibuat grafik untuk menentukan konsentrasi $\mathrm{NaCl}$ pada saat tanaman mati 90\% (Gambar 2). Persamaan garis grafik adalah $\mathrm{y}=-2 \mathrm{E}-10 \mathrm{x}^{3}+4 \mathrm{E}-06 \mathrm{x}^{2}-$ $0.0351 x+98.095$ dengan nilai $\mathrm{R}^{2}=0.9763$. Nilai $\mathrm{R}^{2}$ yang sangat tinggi menunjukkan bahwa sebaran data mendekati sempurna pada grafik. Pada tingkat kematian 90\% atau 10\% tanaman hidup diperoleh pada konsentrasi $\mathrm{NaCl} 3910$ ppm. Pada Gambar 3 dapat dilihat kondisi tanaman kontrol dan tanaman dengan perlakuan $\mathrm{NaCl} 4000$ ppm umur 8 hari. Hal ini seiring dengan penelitian Suwarno (1985) menyatakan bahwa hasil studi fisiologi terhadap tanaman padi yang ditumbuhkan pada larutan hara 4000 ppm $\mathrm{NaCl}$ cukup baik untuk pengujian toleransi terhadap salinitas. 


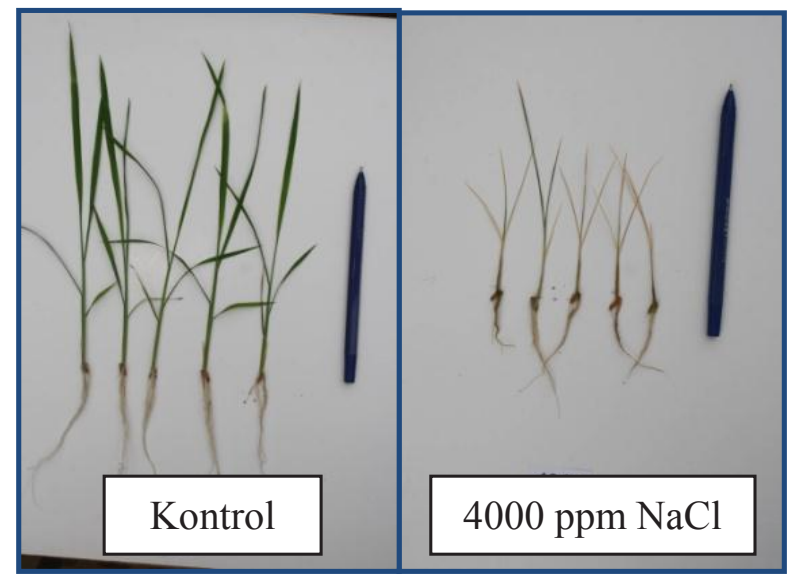

Gambar 3. Perbandingan tanaman kontrol dengan perlakuan $\mathrm{NaCl} 4000$ ppm pada umur 8 hari.

\section{KESIMPULAN}

Perlakuan $\mathrm{NaCl} 4000$ ppm menyebabkan pengurangan tinggi tanaman secara nyata. LD90 untuk tanaman padi pada perlakuan $\mathrm{NaCl}$ diperoleh pada konsentrasi 3910 ppm. Dengan demikian seleksi toleransi salinitas pada padi lokal Bengkulu dapat dilakukan pada konsentrasi $\mathrm{NaCl} 4000$ ppm.

\section{SANWACANA}

Penelitian ini merupakan bagian dari Skim Penelitian Hibah Bersaing tahun 2014 yang didanai oleh Direktorat Jenderal Pendidikan Tinggi.

\section{DAFTAR PUSTAKA}

Anonim_a. 2012. Profil Bengkulu. Pemda Bengkulu. http://bkpmdbkl.net84. net/ profil.html. 26 Maret 2012

Anonim_b. 2012. Protocol salt tolerance screening in rice using hydroponics. http://mvgs.iaea.org/PDF/PBGL_ Salt\%20tolerance\%20_hydroponics

Bhumbla, D. and I. Abrol. 1978. Saline and sodic soils. In Soil and Rice pp 719738. IRRI. Manila
Blake C., R. Munns. 2011. Screening for salt tolerance using supported hydroponics. http://prometheuswiki.publish.csiro.au/ tiki-index.php?page

Hutajulu, H.F., Rosmayati dan S. Ilyas. 2013. Pengujian respons pertumbuhan beberapa varietas padi sawah (Oriza sativa L.) akibat cekaman salinitas. Jurnal online Agroekoteknologi 1(4): 1101-1109

Ibnu-Rusd, A.M. 2011. Pengujian toleransi padi (oryza sativa L.) terhadap salinitas pada fase perkecambahan skripsi. IPB. Bogor

Ismail, A. 2007. Rice tolerance to salinity and other problem soil: Physiological aspects and relevance breeding IRRI lecture in rice breeding course. IRRI Manila

Lafitte H.R., A. Ismail, J. Bennet. 2004. Abiotic stress tolerance in rice for Asia: progress and the future. "New direction for a diverse planet". Proceeding of 4th International Crop Sciences Congress 26 Sep - 1 Okt 2004. Brisbane. Australia. 
Levitt, J. 1980. Responses of Plant to Environmantal stresses. 2nd ed. Academic Press. New York. 607p.

Muttaqiena. 2009. Makalah Pengelolaan Wilayah Pesisir Secara Berkelanjutan Pasca Tsunami Desember 2004. http:// slideshare.net/abida/pengelolaanpesisir. 18 September 2013

Pujiwati, H., D. Satriawan dan Rustikawati. 2012. Analisis kekerabatan 75 plasma nutfah padi lokal Bengkulu. Prosiding symposium dan seminar bersama PERAGI, PERHORTI, PERIPI, HIGI, Bogor, 1-2 Mei 2012.

Simarmata, M., B. W. Simanihuruk dan Rustikawati. 2010. Identifikasi morfologi dan analisa genetik kulitvar padi gogo lokal Provinsi Bengkulu. Prosiding Seminar Nasional dan Rapat Tahunan Dekan, 23-25 Mei 2010. Pp:324-331

Suprapto, A. 2002. Land and water resources development in Indonesia. dalam. FAO. Investment in Land and Water. Proceedings of the Regional Consultation.

Suwarno. 1985. Pewarisan dan fisiologi sifat toleran terhadap salinitas pada tanaman padi. Disertasi. Program Pascasarjana IPB. Bogor

Yoshida, S., D.A. Forno, J.H. Cock, K.A. Gomez. 1976. Laboratory manual for physiological studies of rise. IRRI. Los Banos, Laguna pp.83. 